\title{
Uexküll and the post-modern evolutionism
}

\author{
Kalevi Kull \\ Department of Semiotics, University of Tartu \\ Tiigi 78, 50410 Tartu, Estonia \\ e-mail:kalevi@zbi.ee
}

\begin{abstract}
Jakob von Uexküll's evolutionary views are described and analysed in the context of changes in semiotic and biological thinking at the end of Modern age. As different from the late Modernist biology, a general feature of Post-Modern interpretation of living systems is that an evolutionary explanation has rather secondary importance, it is not obligatory for an understanding of adaptation. Adaptation as correspondence to environment is a communicative, hence a semiotic phenomenon.
\end{abstract}

What does it mean, no longer being able to think a certain thought? Or to introduce a new thought?

Foucault 1989 [1966]: 56

When we can once establish a music theory of life, these simple examples will build its basis.

Uexküll 1937: 195

The typologies of the ages of understanding that Arthur Lovejoy (1964 [1936]) or Michel Foucault (1989 [1966]) have applied to biology and that John Deely (2001) has developed for a whole philosophical thought on the basis of semiotic approach are attractive enough to try to use their models in interpretation of otherwise difficult or even controversial cases of biological thought.

Wenn wir einmal eine Musiktheorie des Lebens werden aufstellen können, werden diese einfachen Beispiele die Grundlage bilden. 
Jakob von Uexküll's views on biological evolution provide a good example of controversial interpretations. As a non-darwinian, he has been occasionally considered an anti-evolutionist. However, it may also be that the conclusions of such kind strongly depend on the typology of views applied, and thus in case if a non-darwinian evolutionism is feasible and scientifically acceptable - and it evidently is feasible - Uexküll's role just changes, becoming an example of evolutionism of a special kind. ${ }^{2}$

A reason why it has been difficult to some interpreters to understand the Uexküll's view, is due to the negligible role he gives to an evolutionary explanation.

This paper has two aims: (1) to review the evolutionary views of Jakob von Uexküll, and (2) to describe very briefly the distinction between the main types of evolutionism, particularly in the context of biosemiotic approach.

\section{Evolutionism in biosemiotics}

What happens to evolutionism, when the modernism is finished? When asking this, I am going to apply here John Deely's (2001) principal division of the history of western thought into four ages Greek, Latin, Modern, and Post-Modern - to the history of natural sciences. The Modern age, accordingly, has lasted from the 17th to the 20th century, and one of its characteristic features has been a belief into a possibility to improve the nature. Particularly in the 19th century, it took a form of a view about a self-improvement of nature i.e., the progressive evolution.

The end of Modernism, as described by John Deely, is characterized by the rise of semiotics. On the one hand, this is exemplified by works of Charles S. Peirce, on the other hand - as Deely emphasizes — via the concepts introduced by Jakob von Uexküll: "[ [...] 'Umwelt' [...] is a term singularly suitable to the needs of semiotics in arriving at the paradigm proper to itself" (Deely 2002: 129-130).

This is a paradigm that can be best characterized by the metaphor of web, as used by Thomas A. Sebeok in the expression of "the semiotic web", and as introduced by Jakob von Uexküll (1992: 327):

\footnotetext{
2 Uexküll's views on evolution have been discussed recently also by Hoffmeyer (2004) and Chien (2004).
} 
"every subject spins his relations to certain characters of the things around him, and weaves them into a firm web which carries his existence" - the latter formulation being said by Deely (2001: 605) the ever best characterization for experience.

Thus, what happens with evolutionism when moving from Modern to Post-Modern, is that we leave behind the whole concept of life's progress as expressed in the tree of life and instead understand the evolution as modifications in the web of life. This is an analogical step to the one that took place in the 17th century, when the Latin concept of the ladder of life was replaced by the tree of life (Lovejoy 1964; Kull 2003).

Uexküll identifies his views to the one that is opposed to the entire different worldview of the modernism, as he says: "We can indeed fix the date of the change [...]. It lies between Kepler and Newton" (Uexküll 2001: 114). He explains: "Kepler suchte nach dem Plan - Newton nach der Ursache der gleichen Erscheinung. [...] Seit Darwin waren die Biologen eifrig bemüht, die Merkseite der Lebewesen zu unterschlagen und nur ihre Wirkseite zu beachten"3 (Uexküll 1937: 188-189).

Though, Uexküll's views on evolution may look unusual - rather these represent an old, pre-modern position. Here, a reference, e.g., to J. Deely's (2001) analysis can be relevant, which demonstrates a series of similarities between the late Latin and Post-Modern approaches.

Uexküllian view on evolution is also a non-cartesian, and an ecological one. In this kind of biology, phylogeny does not serve (in most cases, at least) the role of an ultimate explanation of the design of structures. Instead, for the understanding why biosystems behave like they do, their holistic features, their systemic functioning, or, in other terms, the communicative mechanisms have to be discovered.

Neo-darwinian evolutionism (e.g., Dobzhansky et al. 1977) is modern. Also Lamarckian and Darwinian ones were modern. The evolutionism of modernism is the evolutionism of progress. Ecologicity of neo-darwinism differs from the post-modern ecological view - an emphasis of the former is put on the Red Queen, on competition and the co-evolutionary race of survival, whereas the latter view interprets competition as a special case (imbalance) in symbiotic relationships.

The autogenetic view of biology, developed by Humberto Maturana and Francisco Varela (1980) in their work on autopoiesis, can be

3 Kepler searched for the plan, and Newton for the cause of all manifest creation. From Darwin on, biologists have carefully tried to evade the perception of living beings and have only noted their operation. 
seen, at least partly, similar to that of Uexküll, which was initially inspired by the Kantian view as applied to biological systems. Maturana and Varela (1980: 11) also state that "reproduction and evolution are not essential for the living organization, but they have been essential for the historical transformation of the cognitive domains of the living systems on Earth."

It would not be very easy to classify semiotics into evolutionary sciences, despite of the fact that at least its post-structuralist period deals much with diachronic aspects and historical discontinuities. Ch. Peirce's description of the evolution of habits deals more with developmental continuities, however, it can hardly be taken as a serious model of evolution by a biologist describing the numerical mechanisms in the dynamics of allele frequencies in a population. Nevertheless, semioticians in any case do not deny evolution.

Indeed, the topic of evolution has not been entirely avoided in the writings about the semiotics of nature. Particularly those authors who support Peirce's views, together with Ch. Peirce himself, speak about the growth and development of semiosis. There are for instance works by W. A. Koch (1992), F. Merrell (1992; 1996), W. Nöth (1994) etc. which touch the evolutionary levels of semiosis. However, they very rarely write anything specific about the possible mechanisms of evolution. For instance, a review paper by T. A. Sebeok (1997) entitled "Evolution of semiosis" refers to semiosis in different levels of biological organization without speaking about the evolutionary process itself or its mechanisms. Few exceptions, of course, exist (e.g., Deacon 1997; Heusden 2004; Kull 1992).

As a matter of fact, biosemiotics has been, from its very beginning, quite cautious in making evolutionary statements. In particular, the mechanisms of evolutionary change are rarely analyzed in these works, and the same can also be said about the biosemiotic writings of recent years. "Zumindest aber würde neben eine allgemeine Semiotik, wie wir sie heute kennen, eine allgemeine 'Entwicklungssemiotik' oder besser eine allgemeine genetische Semiotik als Forschungsgebiet und Theorienansatz treten, ähnlich, wie dies auch in der Psychologie oder ansatzweise in der Linguistik der Fall ist" "(Bentele 1984: 11).

4 But at least besides general semiotics, as we know it today, a general 'developmental semiotics', or better a general genetic semiotics as a scientific branch and theoretical field, will be established, in the same way as this has occurred in psychology or for instance in linguistics. 
The bioevolutionary topic in semiotics was occasionally analyzed, particularly one should mention the book by G. Bentele (1984), the works of H. M. Müller (1990; 1993), G. Witzany (1993), P. Bouissac (1993), several papers touching on semiotic aspects of evolutionary epistemology (Schult 1989; Hoffmeyer 1996) a.o. A remarkable paper in which a series of statements on the semiotic aspects of biological evolution is formulated, is the collective article by M. Anderson et al. (1990); e.g., they stress the importance of coevolution and symbiosis. Also, "communication begins with a decoder, not with the encoder, whether 'intentional' or not: This insight is particularly crucial to the understanding of evolution as a part of semiosis. Similarly, life is a result of one of the most interesting innovations with Gaia, namely, death" (Anderson et al. 1990: 762).

S. Salthe (1997) even considers that "semiotics has implicitly been a part of Darwinian concerns more or less from the inception of the discourse. Prominently, we have always interpreted adaptations in organisms as signs of their environment."

Despite several exceptions, it can be concluded that the majority of biosemioticians have been quite critical toward the neo-Darwinian school of thought, appreciating considerably higher the views of the followers of Karl Ernst von Baer (Kull 1998). "Natural selection itself is but one of a number of semiotic processes involved in biological transformation" (Anderson et al. 1990: 756). If so, then it might be rather expected that biosemiotics will contribute to the 'new synthesis' (Hoffmeyer 1997; Odling-Smee 1994; Salthe 1993a), or to postDarwinism (Ho 1989), if it comes about, of course.

A principal issue that makes a divide in the evolutionary approaches is the role assumed for the organisms. Either they are survival-machines automatically selected by the environment, or they are subjects of selection who create their life conditions together with themselves. The latter view has been expressed already by K. E. v. Baer, and by J. M. Baldwin (the concept of organic selection, Baldwin 1896; Belew, Mitchell 1996; Tembrock 1990; Weber, Depew 2003), and in various aspects by L. L. Whyte (the concept of internal selection, Whyte 1965), E. Jablonka (the role of epigenetic inheritance, Jablonka, Lamb 1995; also Ho, Saunders 1979) and F. J. Odling-Smee (the role of niche construction, Odling-Smee et al. 2003). 
A general mechanism of non-selectional origin of evolutionary adaptation (i.e. a non-darwinian type of adaptive evolution) could briefly described as follows (Hoffmeyer, Kull 2003; Kull 1992; 2000).

Adjustment (or acclimatization, or adaptation) to environment is a process that is taking place as a physiological and behavioural one continuously, in all periods of organism's life. This means certain slight changes in the organisms' structure, including in the pattern of gene expression. In case of a permanent change of life conditions (either due to migration into a new location or a change of conditions in the locus), some of these changes may include almost all specimens of the population. Later, some of these adjustments can become irreversible in result of either processes of genetic drift or stabilizing selection, and thus an adaptation has turned into an evolutionarily fixed characteristic.

This sort of mechanism can be called semiotic, because it requires an activity of organisms in acclimatization, in recognizing and selecting their behaviour and their environment. And this is different from, or more general than the mechanism of natural selection that would necessarily require differential reproduction. And this is not a Lamarckian mechanism because it does not assume the inheritance of acquired characters.

Adaptation itself is neither physical nor evolutionary phenomenon - adaptation is a communicative, thus a semiotic phenomenon (of course having certain physical and evolutionary counterparts).

\section{Uexküll's view on evolution ${ }^{5}$}

Uexküll retains a very special place in twentieth century biology. He was, in the beginning of the century, one of those who helped to found theoretical biology, and whose contribution was important in establishing it as a separate field of science (Uexküll 1913; 1920; cf. Alt et al. 1996). And at the end of the century, he has been the one whose views happened to be in the center of a (new) synthesis which heralds the start of post-Darwinian biology (after the long neo-Darwinian period), in a synthesis which generalizes evolutionary theory, in order to make mental phenomena a natural aspect of it (Hoffmeyer 1997).

5 An earlier version of this analysis has been published in Kull 1999. 
As a tool of this synthesis, may serve semiotics. It may be interesting, therefore, to look more closely at this 'Uexküllian tradition'.

Uexküll, when studying zoology and evolution at the lectures of Julius Kennel (1854-1939) at the University of Tartu, was initially fond of Darwinian explanations. However, when Kennel claimed that one can build a phylogenetic tree between any given pair of organisms or species, Uexküll saw in this a play and not serious science. Instead of zoology, he started to be interested in physiology (particularly of marine invertebrates), investigating how physiological mechanisms work in the natural conditions of living nature. He also moved away from the views of Ch. Darwin and E. Haeckel (G. v. Uexküll 1964: 35-36).

In his Theoretische Biologie, Uexküll did not allocate much space to the problems of evolution - for him, evolutionary theory was not directly needed in order to build up a theory of living systems. According to G. Bentele (1984: 114), "die Konzeption, die von Uexküll entwickelt hat, [ist] nicht genetisch im Sinne von 'entwicklungsgeschichtlich' ausgerichtet"6. Below, I will describe Uexküll's evolutionary views in more detail - this is a part of his approach which has usually received less attention, in comparison to his Umwelt-theory.

Uexküll's approach to living systems is based (at least since the second edition of Theoretische Biologie, 1928) on the notion of Funktionskreis - 'functional cycle'. According to this, all behaviour of organisms, all functions of a living body, are expressions of circular acts which include recognition of signs by receptors, actions as induced by these recognitions, and perceptions of the results of these actions.

Instead of H. Driesch's entelechy, Uexküll used the notion of Plan (Uexküll 1929: 36; this is an interesting point, since it is similar to the step made by J. Woodger (1929) and J. Needham (1936), which replaced the rational part of entelechy by 'organising relations', or 'biological organisation'). Plan represents a spatial whole. "Unter Regel verstehen wir die Verknüpfung beliebiger Faktoren zu einer Einheit. Der Plan ist enger gefaßt und bedeutet bloß die Einheit räumlicher Beziehungen""7 (Uexküll 1929: 36).

\footnotetext{
6 The conception developed by Uexküll is not genetic in the sense of 'developmental history'.

7 Under rule we mean the connection of certain factors into a whole. The plan is more strictly defined and means only the whole of spatial relations.
} 
Uexküll sees the functional cycle as an active Plan, the Lebensfaktor, or Mechanisator, which is responsible for an organism's functions, including its growth and regeneration (Uexküll 1929: 39). "Die Funktionsregel selbst ist, die fähig ist, Gefüge zu formen"8 (Uexküll 1973: 217).

Functional cycles are also a basis for the functioning of cells in tissues. "Die lebende Zelle ist der Träger eines eigenen Naturgesetzes - sie ist ein Autonom. [...] Die lebende Zelle verhält sich äußeren Objekten gegenüber nicht als Objekt, sondern als Subjekt", (Uexküll 1931: 386).

Thus, Planmäßigkeit is characteristic to Bauplans. "Nicht aus Reflexen, sondern aus planvollen Funktionskreisen bestehen die Baupläne der Tiere, die zugleich Tier und Umwelt in einer sinnvollen Zusammenhang zueinander bringen"10 (Uexküll 1931: 389). "Die Planmäßigkeit des Körpergefüges und der Planmäßigkeit des Umweltgefüges stehen einander gegenüber und scheinen sich $\mathrm{zu}$ widersprechen"11 (Uexküll 1940: 7). Uexküll sees in this, also, a direct continuation of Baer's views: "Das oberste Gesetz des Lebens, das alle Planmäßigkeit in der Zeit planmäßig zusammenfaßt, hat K. E. von Baer die 'Zielstrebigkeit' genannt"12 (Uexküll 1938: 144). This Baer's term was, much later, replaced by the word 'teleonomy' (in order to make it acceptable for Darwinian school; cf. Mayr 1988).

Uexküll assumes that "jeder Merkplan einen bestimmten Wirkplan induziert" ${ }^{\prime 3}$ (Uexküll 1931: 389). Induktion is the type of interaction which is specific to interactions between subjects (whereas the objectobject interaction is 'mechanical', object-to-subject is Reiz, and subject-to-object is Impuls; Uexküll 1931: 388). The connection between Merkplan and Wirkplan, as well as between subjects, is

8 The functional rule itself is that, which is able to form structures.

9 The living cell is the carrier of its own natural law - she is an autonome. [...] The living cell does not behave in relation to external objects as an object, but as a subject.

10 The Bauplans of animals do not consist of reflexes, but of designed functional cycles, which bring both animal and Umwelt into a meaningful connection.

11 The plan of the body structure and the plan of the Umwelt structure face against and seem to contradict each other.

12 The highest law of life, which connects all plan in time, has been named 'directedness' by K. E. v. Baer.

13 Every sign plan induces a certain operation plan. 
komplementär (Uexküll 1931: 389); the latter means for Uexküll the relationship which is generated by Induktion.

Consequently, the form of organisms is not static, but generative. "Die Morphologie kann man kurz die Wissenschaft der Entstehungszeichen nennen, denn ihre Aufgabe ist es, die Lebewesen nicht in funktionelle, sondern in genetische Bausteine zu zerlegen" ${ }^{\text {"14 }}$ (Uexküll 1973: 226).

It is important to realize that Planmäßigkeit concerns not only spatial, but also temporal aspects of organization. "[...] die Planmäßigkeit nicht bloß das Nebeneinander der Organe im Raum, sondern auch ihr Nacheinander in der Zeit beherrscht" ${ }^{, 15}$ (Uexküll 1925: 7).

Uexküll follows Caspar Friedrich Wolff's epigenetics, and sees the creation of new structures as a result of induction both in ontogeny and phylogeny. Consequently, he accepts the possibility of saltatory evolution, without the existence of all intermediate forms. These are similar to transitions from one motif to another in a musical score. "Obgleich auch bei Raupe und Schmetterling sowie bei Libellenlarve und Libelle die Motive grundverschieden sind, fällt es keinem Menschen ein nach Zwischengliedern zu suchen"16 (Uexküll 1943: 2).

Thure von Uexküll (1980: 59) described his father's evolutionary views with the following words: "[...] Evolution [kann] nicht der Weg des Zufalls sein, der in einer linearen Zeit durch Versuch und Irrtum von unvollkommenen zu besser angepaßten Formen führt, sondern nur die Komposition einer großen Symphonie oder eines umfassenden Code, einer übergreifenden Planmäßigkeit, welche in den verschiedenen Umwelten die gleichen Themata in wechselnder Differenzierung - aber immer gleicher Vollkommenheit — variiert." ${ }^{\text {17 }}$

\footnotetext{
14 Morphology can be shortly defined as a science of developmental signs, whose task is to deconstruct living beings, not into functional, but into genetic [generative, generic] elements.

The plan rules not only the arrangement of organs in space, but also their arrangement in time.

16 In the same way that the motives basically differ for caterpillar and butterfly, and for dragonfly larva and dragonfly, so it is for human intermediate forms.

17 Evolution cannot be a path of chance, leading in a linear time through trial and error from imperfect to better adapted forms, but rather the composition of a great symphony or an extensive code, a far-reaching plan, which varies the same themes in different Umwelten - in different degrees of complexity, but always to the same perfection.
} 
The terms from music, which appear here, are not random examples for Uexküll. He saw in them a possibility to express the holistic features of living systems. "Alles Körperliche läßt sich mit dem Messer zerschneiden - eine Melodie aber nicht"18 (Uexküll 1940: 51). Over the years, the frequency of music metaphors grew in Uexküll's texts.

Uexküll distinguished between Anpassung (fitting) and Einpassung (matching), preferring the latter in the description of adaptations. He criticized the term Anpassung, which has been used to denote the adaptation of organisms to the environment (Umgebung) (Uexküll 1973: 318). "An ihrer Stelle hat die Lehre von der überall gleich vollkommenen Einpassung zu treten, die dreifacher Art ist: 1. besteht eine Einpassung der Organe und Organteile, die den Körper bilden, in- und untereinander; 2. besteht eine Einpassung zwischen Körper und Umwelt; 3. besteht eine Einpassung der Umwelten untereinander" ${ }^{\prime 19}$ (Uexküll 1927: 696). "Wohin wir schauen, erblicken wir [...] komplementäre Einpassungen paarweise aufeinander abgestimmter Umwelten"20 (Uexküll 1931: 391). According to Uexküll (1973: 319), "es gibt kein Mehr oder Weniger bei der Einpassung. Die Einpassung ist immer vollkommen, soweit die dem Tier zur verfügung stehenden Mittel reichen." 21

This emphasis on the reciprocity of interactions in living systems is an important aspect in understanding Uexküll's views. This concerns, for instance, his approach to the role of symbiosis: "man kann sagen, daß grundsätzlich alle Lebewesen zugleich selbstdienlich und fremddienlich sind"22 (Uexküll 1973: 322).

Uexküll highly appreciated the works of Gregor Mendel and August Weismann (Uexküll 1927: 694), but remarked that "so ist die theoretische Bedeutung der Mendelschen Entdeckung bis zum

\footnotetext{
18 All corporeal can be separated with a knife — but not a melody.

19 Instead, a theory on the accomplished matching (complementarity) is developed, which includes three types: 1 . the matching of organs and their parts, which within and between each other make up the body; 2. the matching of bodies and their environment; 3 . the matching of Umwelten.

20 Wherever we look, we see [...] the complementary matching of pairwise mutually harmonised (co-ordinated) Umwelten.

21 There is no more or less in matching. An adaptation is always accomplished, as far as it provides a tool for an animal.

22 It can be said that all living beings are at the same time both self-serving and else-serving.
} 
heutigen Tage noch nicht in ihrem vollen Umfange erkannt worden" 23 (Uexküll 1973: 221), and, noted particularly, that Mendel did not analyze the development of organisms (Uexküll 1927: 694). In the views of Ewald Hering and Richard Semon, Uexküll saw a certain support for Ernst Haeckel's biogenetic law, the former, however, being unacceptable to Darwinists due to the vitalistic inclination of Semon's approach (Uexküll 1927: 695).

Understanding the role of genes, he gives the following example. "Die Tatsache, daß sowohl kurzhalsige wie langhalsige Säugetiere sieben Halswirbel besitzen, beweist, daß die Mutation erst eingesetzt hat, nachdem die sieben Sprossen für die Halswirbel bereits fest angelegt waren. Eine von solchen Gesichtspunkten ausgehende Stammesgeschichte wird aber erst dann möglich sein, wenn die Lehre von der sprungweisen Einpassung die Lehre von der allmählichen Anpassung verdrängt haben wird" "24 (Uexküll 1973: 259).

It can be added that Uexküll's view on species may be interpreted as quite close to the contemporary recognition concept of species (Paterson 1993; Kull 1992). "Ist die Grenze einer Art gegen die andere nur dadurch festgelegt, daß beim Aufeinandertreffen einer allzu großen Zahl von abweichenden Genen aus äußeren physiologischen Gründen bei der Kreuzung ein lebensfähiges Individuum nicht mehr erzeugt werden kann?"25 (Uexküll 1973: 265).

Uexküll leaves his evolutionary views unfinished. As H. Driesch (1921: 203) put it: "Warum ändert sich die Melodie? Wir wissen das nicht." 26 For a biosemiotician, this would give an insight to analyse the processes of evolutionary change in a way similar to the way one would analyse the development of music, sensu lato.

\footnotetext{
23 The theoretical meaning of Mendel's discovery is not yet fully understood.

24 The fact that both short-necked and long-necked mammals have seven cervical vertebrae, shows that the mutation first appeared, after the seven primordia for cervical vertebrae had already appeared. A phylogeny based on this view can be possible after a theory of saltatory matching has replaced the theory of gradual fitting.

25 Is a species boundary in relation to some other species drawn only by the fact that the interaction of a large number of genes due to external physiological reasons does not produce a living individual?

26 Why does the melody change? We do not know.
} 


\section{Concluding remarks}

In a typology of views, both synchronic and diachronic divisions should be considered.

As synchronic, for instance, A. Lyubischev's (2000) two great lines in the history of philosophy, the line of Democritos and the line of Plato, have been described. Similarly, the Darwinian and von Baerian biology. Or, why not, a physical versus semiotic biology.

As diachronic, the four ages in the history of philosophical thinking according to J. Deely, or the periodization A. Lovejoy introduced for interpretation of nature in the ladder-tree-web series. Or, the epistemes as described by M. Foucault.

One and the same opposition can also create both - the opposing views of contemporaries, and the periods of dominant view - like the epigenetic-preformist opposition in biology of many centuries.

Moreover, the typology would be deficient if we would not take into account the continualist views to science. This also has both synchronic and diachronic dimension. According to the 'diachronic continualism', the science, e.g., biology, or evolutionism, is either a cumulative or just ever-changing set (or system) of knowledge, where the revolutions hardly occur. And according to a 'synchronic continualism', we just have many versions of understanding simultaneously co-existing that do not possess a real hiatus required for different types to really exist.

All this considered, it would be attractive to make a more thorough inquiry of the fundamental turn in biological understandings that can be called 'an end of modern biology', or 'a start of post-modern'.

\section{References}

Alt, Wolfgang; Deutsch, Andreas; Kamphuis, Andrea; Lenz, Jürgen; Pfistner, Beate 1996. Zur Entwicklung der theoretischen Biologie: Aspekte der Modellbildung und Mathematisierung. Jahrbuch für Geschichte und Theorie der Biologie 3: 7-60.

Anderson, Myrdene; Deely, John; Krampen, Martin; Ransdell, Joseph; Sebeok, Thomas A.; Uexküll, Thure von 1990. Global view of sciences and semiotics. In: Koch, W. A. (ed.), Semiotics in the Individual Sciences, Part II. Bochum: Universitätsverlag Dr. N. Brockmeyer, 741-784.

Baldwin, James Mark 1896. A new factor in evolution. American Naturalist 30: 441-451, 536-553. 
Bax, Marcel; Heusden, Barend van; Wildgen, Wolfgang 2004. Semiotic Evolution and the Dynamics of Culture. Bern: Peter Lang.

Belew, R. K.; Mitchell, M. (eds.). 1996. Adaptive Individuals in Evolving Populations: Models and Algorithms. Reading: Addison-Wesley.

Bentele, Günter 1984. Zeichen und Entwicklung: Vorüberlegungen zu einer genetischen Semiotik. (Kodikas/Code suppl. 15.) Tübingen: G.Narr.

Bouissac, Paul 1993. Semiotisches Wettrüsten: zur Evolution artübergreifender Kommunikation. Zeitschrift für Semiotik 15(1-2): 3-21.

Chien, Jui-Pi 2004. Sign Systems Studies 32(1/2): 187-208.

Deacon, Terrence 1997. The Symbolic Species: The Coevolution of Language and the Brain. New York: Norton.

Deely, John 2001. Four Ages of Understanding: The First Postmodern Survey of Philosophy from Ancient Times to the Turn of the Twenty-first Century. Toronto: University of Toronto Press.

- 2002. What Distinguishes Human Understanding? South Bend: St. Augustine's Press.

Dobzhansky, Theodosius; Ayala, Francisco J.; Stebbins, G. Ledyard; Valentine, James W. 1977. Evolution. San Francisco: W.H.Freeman.

Driesch, Hans 1921. Besprechung: Uexküll, J. von, Theoretische Biologie. KantStudien 26: 201-204.

Foucault, Michel 1989 [1966]. The Order of Things: An Archeology of the Human Sciences. London: Routledge.

Heusden, Barend van 2004. A bandwidth model of semiotic evolution. In: Bax et al. 2004: 3-33.

Ho, Mae-Wan 1989. A structuralist of process: Towards a Post-Darwinian rational morphology. In: Goodwin, B. C.; Sibatani, A.; Webster, G. C. (eds.), Dynamic Structures in Biology. Edinburgh: Edinburgh University Press, 31-48.

Ho, Mae-Wan; Saunders, P. T. 1979. Beyond neo-Darwinism - an epigenetic approach to evolution. Journal of Theoretical Biology 78: 573-591.

Hoffmeyer Jesper 1996. Evolutionary intentionality. In: Pessa, E.; Penna, M. P.; Montesanto, A. (eds.), Third European Congress on Systems Science, Rome 1-4 Oct. 1996. Rome: Edizioni Kappa, 699-703.

- 1997. Biosemiotics: Towards a new synthesis in biology. European Journal for Semiotic Studies 9(2): 355-376.

— 2004. Uexküllian Planmessigkeit. Sign Systems Studies 32(1/2): 73-97.

Hoffmeyer, Jesper; Kull, Kalevi 2003. Baldwin and biosemiotics: What intelligence is for. In: Weber, Bruce; Depew, David (eds.), Evolution and Learning: The Baldwin Effect Reconsidered. Cambridge: MIT Press, 253-272.

Jablonka, Eva; Lamb, Marion J. 1995. Epigenetic Inheritance and Evolution: The Lamarckian Dimension. Oxford: Oxford University Press.

Koch, Walter A. 1992. Ecogenesis and echogenesis: some problems for biosemiotics. In: Sebeok, Thomas A.; Umiker-Sebeok, Jean (eds.), Biosemiotics: The Semiotic Web 1991. Berlin: Mouton de Gruyter, 171-211.

Kull, Kalevi 1992. Evolution and semiotics. In: Sebeok, Thomas A.; Umiker-Sebeok, Jean (eds.), Biosemiotics: The Semiotic Web 1991. Berlin: Mouton de Gruyter, 221-233. 


\section{Kalevi Kull}

- 1998. Biosemiotics in the twentieth century: a view from biology. Semiotica 127(1/4): 385-414.

- 1999. Umwelt and evolution: From Uexküll to post-darwinism. In: Taborsky, Edwina (ed.), Semiosis, Evolution, Energy: Towards a Reconceptualization of the Sign. Aachen: Shaker Verlag, 53-70.

- 2000. Organisms can be proud to have been their own designers. Cybernetics and Human Knowing 7(1): 45-55.

- 2003. Ladder, tree, web: The ages of biological understanding. Sign Systems Studies 31(2): 589-603.

Lovejoy, Arthur O. 1964 [1936]. The Great Chain of Being. Cambridge: Harvard University Press.

Lyubischev, Aleksandr A. 2000. Linii Demokrita i Platona v istorii kul'tury. Sankt-Peterburg: Aletejya.

Maturana, Humberto R.; Varela, Francisco J. 1980. Autopoiesis and Cognition: The Realization of the Living. Dordrecht: D. Reidel Publ. Co.

Mayr, Ernst 1988. Toward a New Philosophy of Biology: Observations of an Evolutionist. Cambridge: Harvard University Press.

Merrell, Floyd 1992. As signs grow, so life goes. In: Sebeok, Thomas A.; UmikerSebeok, Jean (eds.), Biosemiotics: The Semiotic Web 1991. Berlin: Mouton de Gruyter, 251-281.

- 1996. Signs Grow: Semiosis and Life Processes. Toronto: University of Toronto Press.

Müller, Horst M. 1990. Sprache und Evolution: Grundlagen der Evolution und Ansätze einer evolutionstheoretischen Sprachwissenschaft. Berlin: de Gruyter.

- 1993. Die Entwicklung von Interaktion, Semiose und Sprache. Zeitschrift für Semiotik 15(1-2): 81-106.

Needham, Joseph 1936. Order and Life. New Haven: Yale University Press.

Nöth, Winfried (ed.) 1994. Origins of Semiosis: Sign Evolution in Nature and Culture. Berlin: Mouton de Gruyter.

Odling-Smee, F. John 1994. Niche construction, evolution and culture. In: Ingold, Tim (ed.), Companion Encyclopedia of Anthropology. London: Routledge, 162196.

Odling-Smee, F. John; Laland, Kevin N.; Feldman, Marcus W. 2003. Niche Construction: The Neglected Process in Evolution. Princeton: Princeton University Press.

Paterson, Hugh E. H. 1993. Evolution and the Recognition Concept of Species. Baltimore: The J.Hopkins Univ. Press.

Salthe, Stanley N. 1993a. Development and evolution as aspects of self-organization. In: Sintonen, M.; Sirén, S. (eds.), Theory of Evolution - In Need of a New Synthesis? Tampere: Fitty, 5-18.

- 1993b. Should prediction or historical uniqueness be the central focus of biology? Folia Baeriana 6: 247-260.

- 1997. Semiotics in biology: inside neo-Darwinism. Revue de la Pensee d'aujourd'hui 25(7): 128-139. 
Schult, Joachim 1989. Biosemiotik - Gegenstandsbereiche und Anwendungsmöglichkeiten: Anmerkungen zum Verhältnis von Biologie und Semiotik. Kodikas/Code 12(3/4): 261-274.

Sebeok, Thomas A. 1997. The evolution of semiosis. In: Posner, Roland; Robering, Klaus; Sebeok, Thomas A. (eds.), Semiotics: A Handbook on the SignTheoretic Foundations of Nature and Culture, vol. 1. Berlin: Walter de Gruyter, 436-446.

Tembrock, Günter. 1990. Lernen und Evolution: Lernbedingtes Verhalten, verhaltensbedingtes Lernen. In: Geissler, E.; Tembrock, G. (eds.), Natürliche Evolution von Lernstrategien. Berlin: Akademie-Verlag, 1-19.

Uexküll, Gudrun von 1964. Jakob von Uexküll: seine Welt und seine Umwelt. Hamburg: C.Wegner.

Uexküll Jakob von 1913. Bausteine zu einer biologischen Weltanschauung. München: Bruckmann.

- 1920. Theoretische Biologie. Berlin: Gebr. Paetel.

- 1925. Die Bedeutung der Planmäßigkeit für die Fragestellung in der Biologie. W.Roux' Archiv für Entwicklungsmechanik der Organismen 106: 6-10.

- 1927. Die Einpassung. In: Bethe, A.; Bergmann, G. v.; Embden, G.; Ellinger, A. (eds.), Handbuch der normalen und pathologischen Physiologie mit Berücksichtigung der experimentellen Pharmakologie, Bd. 1. Berlin: J. Springer, 693-701.

- 1928. Theoretische Biologie. (2. gänzl. neu bearb. Aufl.) Berlin: J.Springer.

- 1929. Plan und Induktion. W. Roux' Archiv für Entwicklungsmechanik der Organismen 116(1): 36-43.

- 1931. Die Rolle des Subjekts in der Biologie. Die Naturwissenschaften 19(19): 385-391.

- 1937. Die neue Umweltlehre: Ein Bindeglied zwischen Natur- und Kulturwissenschaften. Die Erziehung 13(5): 185-199.

- 1938. Das Werden der Organismen und die Wunder der Gene. In: Dennert, E. (ed.), Die Natur - das Wunder des Gottes. Berlin: M.Warneck, 135-144.

- 1940. Bedeutungslehre. (BIOS: Abhandlungen zur theoretischen Biologie und ihrer Geschichte, sowie zur Philosophie der organischen Naturwissenschaften, Bd. 10.) Leipzig: J.A.Barth.

- 1943. Darwins Verschulden. Deutsche Allgemeine Zeitung 82(22/23): 1-2.

- 1973 [1928]. Theoretische Biologie. Frankfurt am Main: Suhrkamp.

- 1992 [1934]. A stroll through the world of animals and men: A picture book of invisible worlds. Semiotica 89(4): 319-391.

- 2001 [1937]. The new concept of Umwelt: A link between science and the humanities. Semiotica 134(1/4): 111-123.

Uexküll Thure von 1980. Plädoyer für eine sinndeutende Biologie: Die Bedeutung der Lehre Jakob von Uexkülls für die Wissenschaften vom Menschen. In: Uexküll, Jakob von, Kompositionslehre der Natur: Biologie als undogmatische Naturwisenschaft (Uexküll, Thure von, ed.). Frankfurt am Main: Ullstein, 17-85.

Weber, Bruce; Depew, David (eds.), Evolution and Learning: The Baldwin Effect Reconsidered. Cambridge: MIT Press. 


\section{Kalevi Kull}

Whyte, Lancelot Law 1965. Internal Factors in Evolution. London: Tavistock. Witzany Günther 1993. Zeichenprozesse als Bedingungen der Möglichkeit von Leben und Evolution: zur Notwendigkeit einer Molekularpragmatik. Zeitschrift für Semiotik 15(1-2), 107-125.

Woltereck, Richard 1932. Grundzüge einer allgemeinen Biologie: die Organismen als Gefüge/Getriebe, als Normen und als erlebende Subjekte. Stuttgart: F. Enke.

Woodger, Joseph H. 1929. Biological Principles. London: Kegan Paul.

\section{Юкскюлл и постмодернистский эволюционизм}

Взгляды на эволюцию Якоба фон Юкскюлла рассматриваются на фоне тех изменений, которые имели место в семиотическом и биологическом мышлении с переходом от модернизма к постмодернизму. Одной из особенностей постмодернистских интерпретаций живых систем является второстепенность эволюционистских объяснений, в отличии от модернистской биологии, которая считала эволюционистское объяснение основным в объяснении биологии. Все же эволюционистское объяснение не является обязательным при объяснении, например, явления адаптации, так как в этом случае мы имеем дело с коммуникативным соответствием (между организмом и средой), т.е. с семиотическим явлением.

\section{Uexküll ja uusajajärgne evolutsionism}

Jakob von Uexkülli evolutsioonialaseid vaateid analüüsitakse nende muutuste taustal, mis on leidnud aset semiootilistes ja bioloogilistes arusaamades seoses üleminekuga modernismilt postmodernismile. Elussüsteemide postmodernsete tõlgenduste üheks iseäraks on evolutsiooniliste seletuste teisejärgulisus, erinevalt hilismodernistlikust bioloogiast, mis pidas evolutsioonilist seletust bioloogia peamiseks seletusviisiks. Ometi pole evolutsiooniline seletus esmatarvilik näiteks adaptatsiooni seletamisel, kuivõrd adaptatsiooni puhul on tegu kommunikatiivse vastavusega (organismi ja keskkonna vahel), seega semiootilise nähtusega. 